Pak. j. sci. ind. res. Ser. A: phys. sci. 2016 59(3)126-129

\title{
Chemical Characterisation of Unrefined Rock Salt Deposits of Pakistan
}

\author{
Abrar ul Hassan**, Sakhawat Ali ${ }^{\mathrm{b}}$, Ayesha Mohy Udd Din a and Salman Muhsen ${ }^{\mathrm{a}}$ \\ ${ }^{a}$ Department of Chemistry, University of Management and Technology, Joher Town, Lahore, Pakistan \\ ${ }^{b}$ Food and Biotechnology Research Centre, PCSIR Laboratories Complex, Lahore-54600 Pakistan
}

(received August 19, 2015; revised April 8, 2016; accepted April 15, 2016)

\begin{abstract}
Different salt samples from mining sites of Bahadur Khel, Warcha and Jatta salt mines were collected during a survey to evaluate their parameters of purity like water insoluble matter, calcium, magnesium, sulphate and potassium contents.Trace elements such as iron, zinc, copper, mangansese, chromium, lead and cadmium were determined by using Atomic absorption Spectrophotometer.Obtained results have shown that of all the three salt deposits, Bahadur Khel salt deposits have a of low purity of $97 \%$ set by codex alimentarius commission. Trace element contents of all the salt deposits were within the legal limits of human consumption and RDA specification.
\end{abstract}

Keywords: atomic absorption spectroscopy, rock salt, moisture content, trace elements

\section{Introduction}

Rock salt comprising of mainly sodium chloride is the essential part of human diet being a food additive, a seasoning and flavouring agent (Cheraghali et al., 2010). In small quantities, it is inevitable to plants and animals but excess amount may lead to serious health problems (Morris et al., 2008). $\mathrm{NaCl}$ provides two major ions, sodium $\left(\mathrm{Na}^{+}\right)$and chloride $\left(\mathrm{Cl}^{-}\right)$as well as traces of calcium $\left(\mathrm{Ca}^{+2}\right)$ and magnesium $\left(\mathrm{Mg}^{+2}\right)$ and traces of minerals which are essential for the proper functioning of living systems (Gong et al., 1997). In addition of a flavouring and seasoning agent, salt regulates the acid alkali balance of body and serves as an electrolyte in body fluids. Also rock salt is employed as a raw material to produce calcium chloride, chlorine gas, chlorine dioxide, caustic soda and as and antifreeze during the ice cream manufacturing. Contamination of table salt even at very low level may lead to serious problems (Heshmati et al., 2014). Trace elements may enter to living systems by exposure to environmental samples like water, salt and food (Scheen and Giet, 2012; Zukowska and Biziuk, 2008).

In Pakistan both the lake and rock salt deposits are present as one of the largest salt deposits in the world in Khewra, Warcha, Jatta and Bahadur Khel. (Alan et al., 1975). Sea salt is found along the coastal areas of Sindh and Balochistan. Bahadur Khel salt in district Kohat is bedded salt which is spread over $12 \mathrm{~km}$ of length and about $1 \mathrm{~km}$ of width. 10.54 billion tonnes of rock salt has been estimated by Geological Survey

*Author for correspondence; E-mail: hassanabrar428@yahoo.com of Pakistan (Faruqi, 1983). Warcha salt mines are located $276 \mathrm{~km}$ away from south of Islamabad in district Khushab, Punajab. Total resources of Warcha salt mines are reported to be billion tonnes. Crystals of Warcha salt mines range from white to pink and mining is through the method of room and pillars.Jatta salt mines are located $217 \mathrm{~km}$ away from Islamabad and considered from tertiary geological horizon. Salt crystals are white, light or grey. Total salt resources are estimated to over few billion of tonnes.

Levels of trace elements in salt samples should be check from time to time because of its frequent use in daily life. Usage of unrefined salt has been prohibited by various health agencies (Soylak et al., 2008) because it has lesser purity levels. Researchers are on the way for mineral profiling of rock salt deposits of Pakistan (Alan et al., 1975). During the present research, salt samples were collected from the three mining sites which include Bahadur Khel, Warcha and Jatta salt mines for their complete characterization. Purpose of this research was to evaluate their impact on public health and their utility as industrial raw material.

\section{Materials and Methods}

Collection of samples. Rock salt samples were collected from the mining sites of Warcha, Jatta and Bahadur Khel during a survey. Samples were collected about 20 $\mathrm{cm}$ below the mining sites and after collection they were immediately kept in the polyethylene bags to be brought into laboratory where they were crushed into 60 meshes and transformed into air tight labeled plastic 
bottles. Samples were opened in the laboratory for their analytical parameters and heavy metal content.

Sample preparation. Crushed samples (5 g of each) was dissolved in $25 \mathrm{~mL}$ of water. Resulting solution was then filtered. Filtrate was diluted to $100 \mathrm{~mL}$ to analyze further by ASTM (2002).

Sulphate content. Stock solution $40 \mathrm{~mL}$ was diluted to $200 \mathrm{~mL}$ in $400 \mathrm{~mL}$ beaker. Few drops of methyl orange were dissolved in it. Solution was gently heated to boiling and $10 \mathrm{~mL}$ of $\mathrm{BaCl}_{2}$ solution was added slowly during stirring. Solution was digested below its boiling point for $30 \mathrm{~min}$ on hot plate. After heating, solution was cooled overnight. Solution was filtered using a Gooch crucible and filtrate was washed in order to ensure no chlorides. Crucible was dried for $15 \mathrm{~min}$. at $110{ }^{\circ} \mathrm{C}$ followed by its ignition in Muffle furnace for $30 \mathrm{~min}$. at $800^{\circ} \mathrm{C}$, and it was cooled in desiccators to weigh. Percentage of sulphate in the salt samples was determined using the following formula.

$$
\text { weight } \% \text { of sulphate }=\frac{\mathrm{A}}{\mathrm{B}} \times 0.4115 \times 100
$$

where;

$$
\begin{aligned}
& A=\text { weight in } g \text { of precipitate } \\
& B=\text { weight in } g \text { of salt in } 40 \mathrm{~mL} \text { of stock soln. }
\end{aligned}
$$

Calcium and magnesium. Two beakers of $400 \mathrm{~mL}$ were taken and $10 \mathrm{~mL}$ of stock solution of rock salt sample was poured in them. One beaker was for the determination of total calcium and magnesium, while one for only calcium. For calcium and magnesium, $5 \mathrm{~mL}$ of buffer solution $1 \mathrm{~mL} \mathrm{KCN}$ solution and a sufficient amount of Eriochrome black T solution was added to a beaker. Then this solution was shifted to an other beaker. This solution was titrated against the standard solution of EDTA till the end point was blue colour.

Acid digestion of samples. Slurry was made by dissolving $5 \mathrm{~g}$ of each of salt sample with $10 \mathrm{~mL} \mathrm{HNO}_{3}$. After heating below the boiling point for $15 \mathrm{~min}$, its volume was made up to $100 \mathrm{~mL}$ by doubly distilled water. Solution was then heated at $110^{\circ} \mathrm{C}$ for $30 \mathrm{~min}$ in order to ensure complete digestion of samples. Solutions were cooled overnight to analyze by Atomic absorption spectrophotometer (ASS) (Hitachi Z 8000, Japan) as depicted in Table 1. Rock salt samples were undergone through analysis for their trace minerals contents of $\mathrm{Fe}, \mathrm{Cr}, \mathrm{Zn}, \mathrm{Cu}, \mathrm{Cd}, \mathrm{Pb}$ and $\mathrm{Mn}$ by Atomic absorption spectrophotometer. Calibration curves were made diluting the commercial BDH metal standards of high purity (APHA, B3050).
Table 1. Specifications of AAS

\begin{tabular}{lllll}
\hline \hline Metals & $\lambda(\max )$ & Flame gases & Sensitivity & $\begin{array}{l}\text { Maximum } \\
\text { lamp current }\end{array}$ \\
\hline $\mathrm{Cd}$ & 228.8 & Air-acetylene & 1.5 & 8 \\
$\mathrm{Cr}$ & 357.9 & Nitrous oxide & 4 & 12 \\
$\mathrm{Cu}$ & 324.8 & Air-acetylene & 4 & 10 \\
$\mathrm{Fe}$ & 248 & Air-acetylene & 5 & 30 \\
$\mathrm{Mn}$ & 279.5 & Air-acetylene & 2.5 & 20 \\
$\mathrm{~Pb}$ & 283.3 & Air-acetylene & 20 & 15 \\
$\mathrm{Zn}$ & 213.9 & Air-acetylene & 1 & 10 \\
\hline \hline
\end{tabular}

\section{Results and Discussion}

Three mining sites producing the rock salt were selected on the basis of their quality to be evaluated chemically using standard methods. Parameters employed for their chemical evaluation were moisture content, water insoluble matter, calcium, magnesium and sulphate content. The results obtained of all the analytical parameters are enlisted in Table 2 ( $a-b)$ for Bahadur Khel salt mines, Table 3(a-b) for Warcha salt mines and Table 4(a-b) for Jatta salt mines.

Water insoluble matter was determined by gravimetric method; Bahadur khel salt samples relatively had higher values of 3.4 to $3.6 \%$ as compared to Warcha and Jatta salt deposits having water insoluble matter in the range of 0.37 to $1.56 \%$ and 0.69 to $2.31 \%$, respectively. Sulphate content of all salt samples was also determined by gravimetric method, and ranges values from 2.13 to $2.23 \%$ for Bahadur Khel, 0.3 to $0.32 \%$ for Warcha and 0.19 to $0.23 \%$ for Jatta salt mine salts. Amount of calcium and magnesium was determined as calcium and magnesium and Calcium only. Magnesium was determined using the method of difference. Calcium in all Bahadur Khel salt samples were in the range of 1.43 to $1.75 \%$ for Warcha salt mines its range was 0.21 to $0.23 \%$ while for Jatta salt samples it was 0.43 to $0.52 \%$. Magnesum range from 0.8 to $0.16 \%, 0.09$ to $0.13 \%$ and 0.01 to $0.02 \%$ for Bahadur Khel, Warcha and Jatta salt mines, respectively. All values of above parameters were in the range set by Codex Alimentarius Commission (CAC, 2006). Only water insoluble matter in Bahadur Khel salt sample had a higher value. Water insoluble matter in previously reported data were higher than the present results (Sharif et al., 2007). Present results have shown that salt from Bahadur Khel has least purity of all samples collected from the mining site (Fig. 1).

Atomic absorption analysis results of heavy metals are enlisted in Table 2(a), 3(a) and 4(a) for respective 
Table 2(a) Analytical parameters of Bahadur khel salt mines

\begin{tabular}{|c|c|c|c|c|c|c|}
\hline \multirow[t]{2}{*}{ Sample } & $\mathrm{NaCl}$ & Moisture & $\mathrm{Ca}^{+2}$ & $\mathrm{Mg}^{+2}$ & $\mathrm{SO}_{4}^{-2}$ & water insoluble \\
\hline & \multicolumn{6}{|c|}{$(\%)$} \\
\hline 1 & 92.02 & 0.12 & 1.75 & 0.16 & 2.15 & 3.5 \\
\hline 2 & 93.1 & 0.13 & 1.62 & 0.14 & 2.21 & 3.4 \\
\hline 3 & 93.2 & 0.14 & 1.44 & 0.13 & 2.23 & 3.4 \\
\hline 4 & 93.1 & 0.12 & 1.43 & 0.12 & 2.19 & 3.6 \\
\hline 5 & 92.8 & 0.11 & 1.47 & 0.11 & 2.2 & 3.4 \\
\hline 6 & 92.6 & 0.12 & 1.49 & 0.13 & 2.13 & 3.3 \\
\hline 7 & 92.3 & 0.12 & 1.73 & 0.8 & 2.23 & 3.4 \\
\hline
\end{tabular}

Table 2(b)Trace elements in Bahadur khel salt mines

\begin{tabular}{llllllll}
\hline \hline $\begin{array}{l}\text { Sample } \\
\text { number }\end{array}$ & $\mathrm{Fe}$ & $\mathrm{Zn}$ & $\mathrm{Cu}$ & $\mathrm{Mn}$ & $\mathrm{Cr}$ & $\mathrm{Pb}$ & $\mathrm{Cd}$ \\
\cline { 2 - 7 } & \multicolumn{7}{c}{$(\mathrm{mg} / \mathrm{kg})$} \\
\hline 1 & 0.61 & 0.19 & 0.02 & $\mathrm{ND}^{*}$ & 0.29 & 0.03 & $\mathrm{~N} \mathrm{D}$ \\
2 & 0.58 & 0.18 & 0.03 & $\mathrm{ND}$ & 0.28 & $\mathrm{ND}$ & $\mathrm{N} \mathrm{D}$ \\
3 & 0.6 & 0.21 & 0.04 & $\mathrm{ND}$ & 0.31 & 0.1 & $\mathrm{~N} \mathrm{D}$ \\
4 & 0.63 & 0.22 & 0.05 & 0.01 & 0.3 & 0.2 & $\mathrm{~N} \mathrm{D}$ \\
5 & 0.61 & 0.24 & 0.06 & 0.01 & 0.29 & 0.21 & $\mathrm{~N} \mathrm{D}$ \\
6 & 0.62 & 0.21 & 0.05 & $\mathrm{ND}$ & 0.28 & 0.23 & $\mathrm{~N} \mathrm{D}$ \\
7 & 0.59 & 0.2 & 0.05 & 0.06 & 0.29 & $\mathrm{ND}$ & $\mathrm{N} \mathrm{D}$ \\
Detection & $0.02-$ & 0.005 & 0.01 & 0.001 & 0.01 & 0.001 & 0.01 \\
Limit & & & & & & & \\
Codex & & 2 & & & & 2 & 0.5 \\
\hline \hline
\end{tabular}

Table 3 (a). Analytical parameters of Warcha salt mines

\begin{tabular}{lllllll}
\hline \hline \multirow{2}{*}{ Sample } & $\mathrm{NaCl}$ & \multicolumn{2}{c}{ Water insoluble $\mathrm{Ca}^{+2}$} & $\mathrm{Mg}^{+2}$ & $\mathrm{SO}_{4}^{-2}$ & Moisture \\
\cline { 2 - 7 } & \multicolumn{7}{c}{$(\%)$} \\
\hline 1 & 97.5 & 1.56 & 0.2 & 0.1 & 0.31 & 0.11 \\
2 & 98.6 & 0.37 & 0.21 & 0.1 & 0.3 & 0.11 \\
3 & 98.2 & 0.77 & 0.22 & 0.09 & 0.29 & 0.12 \\
4 & 98.1 & 0.85 & 0.22 & 0.1 & 0.29 & 0.11 \\
5 & 97.9 & 1.02 & 0.22 & 0.12 & 0.3 & 0.13 \\
6 & 97.6 & 1.27 & 0.23 & 0.13 & 0.32 & 0.14 \\
7 & 98.6 & 2.3 & 0.22 & 0.12 & 0.29 & 0.1 \\
\hline \hline
\end{tabular}

Table 3(b). Trace elements in Warcha salt mines

\begin{tabular}{llllllll}
\hline \hline $\begin{array}{l}\text { Sample } \\
\text { number }\end{array}$ & $\mathrm{Fe}$ & $\mathrm{Zn}$ & $\mathrm{Cu}$ & $\mathrm{Mn}$ & $\mathrm{Cr}$ & $\mathrm{Pb}$ & $\mathrm{Cd}$ \\
\hline \cline { 2 - 7 } & \multicolumn{7}{c}{$(\mathrm{mg} / \mathrm{kg})$} \\
2 & 0.97 & 0.19 & 0.03 & $\mathrm{ND}$ & 0.32 & 0.04 & $\mathrm{ND}$ \\
3 & 0.96 & 0.21 & 0.1 & 0.1 & 0.28 & 0.12 & $\mathrm{ND}$ \\
4 & 0.87 & 0.21 & $\mathrm{ND}$ & 0.04 & 0.27 & $\mathrm{ND}$ & $\mathrm{ND}$ \\
5 & 0.97 & 0.18 & 0.12 & $\mathrm{ND}$ & 0.23 & $\mathrm{ND}$ & $\mathrm{ND}$ \\
6 & 0.93 & 0.19 & 0.11 & $\mathrm{ND}$ & 0.35 & $\mathrm{ND}$ & $\mathrm{ND}$ \\
7 & 0.94 & 0.21 & 0.12 & 0.2 & 0.33 & 0.12 & $\mathrm{ND}$ \\
Detection & 0.99 & 0.23 & $\mathrm{ND}$ & 0.17 & 0.32 & 0.13 & $\mathrm{ND}$ \\
limit & 0.005 & 0.01 & 0.001 & 0.01 & 0.001 & 0.01 \\
Codex & & & & & & & \\
\hline \hline
\end{tabular}

$\mathrm{ND}=$ not deteted
Table 4(a) Analytical parameters of Jatta salt mines.

\begin{tabular}{lllllll}
\hline \hline Sample & $\mathrm{NaCl}$ & Water insoluble & $\mathrm{Ca}^{+2}$ & $\mathrm{Mg}^{+2}$ & $\mathrm{SO}_{4}^{-2}$ & Moisture \\
\cline { 2 - 7 } & \multicolumn{7}{c}{$(\%)$} \\
\hline 1 & 97.5 & 1.57 & 0.47 & 0.01 & 0.23 & 0.12 \\
2 & 96.7 & 2.31 & 0.52 & 0.01 & 0.19 & 0.11 \\
3 & 96.9 & 2.21 & 0.51 & 0.01 & 0.21 & 0.14 \\
4 & 97.2 & 1.86 & 0.5 & 0.02 & 0.23 & 0.14 \\
5 & 98.5 & 0.69 & 0.47 & 0.01 & 0.21 & 0.13 \\
6 & 97.3 & 1.72 & 0.43 & 0.02 & 0.22 & 0.14 \\
\hline \hline
\end{tabular}

Table 4(b) Trace elements in Jatta salt mines

\begin{tabular}{llllllll}
\hline \hline $\begin{array}{l}\text { Sample } \\
\text { no. }\end{array}$ & $\mathrm{Fe}$ & $\mathrm{Zn}$ & $\mathrm{Cu}$ & $\mathrm{Mn}$ & $\mathrm{Cr}$ & $\mathrm{Pb}$ & $\mathrm{Cd}$ \\
\cline { 2 - 8 }$(\mathrm{mg} / \mathrm{kg})$ \\
1 & 1.61 & 0.24 & 0.05 & 0.04 & 0.41 & 0.04 & $\mathrm{ND}$ \\
2 & 1.65 & 0.29 & 0.2 & 0.1 & 0.37 & 0.07 & $\mathrm{ND}$ \\
3 & 1.58 & 0.25 & 0.21 & 0.05 & 0.41 & 0.08 & $\mathrm{ND}$ \\
4 & 1.57 & 0.24 & 0.23 & 0.06 & 0.45 & 0.09 & $\mathrm{ND}$ \\
5 & 1.57 & 0.24 & 0.21 & 0.04 & 0.45 & 0.09 & $\mathrm{ND}$ \\
6 & 1.54 & 0.27 & 0.22 & 0.07 & 0.47 & 0.08 & $\mathrm{ND}$ \\
7 & 1.47 & 0.26 & 0.23 & 0.12 & 0.41 & 0.7 & $\mathrm{ND}$ \\
Detection & $0.02-$ & 0.005 & 0.01 & 0.001 & 0.01 & 0.001 & 0.01 \\
Limit & & & & & & & \\
Codex & & & 2 & & & 2 & 0.5 \\
\hline \hline
\end{tabular}

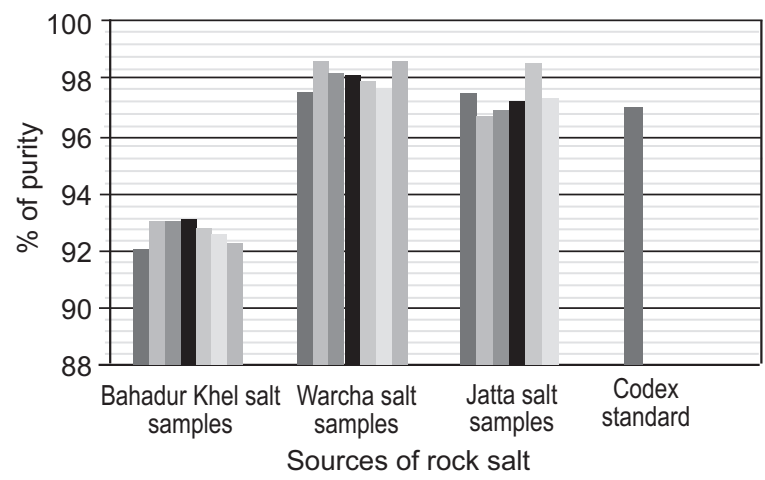

Fig. 1. Percent purity of $\mathrm{NaCl}$ samples vs their sources

resources. A slight variation of these heavy metals above or below the allowed limits can lead to serious metabolic malfunctions as both excess or deficiency of these minerals is critical for living systems (Chen et al., 2011).

In addition to its role in metabolism and as catalyst, iron is important biologically being the part of various living components such as heme pigments, myoglobin etc. (Aktas and Ibar, 2005). Permissible limit for iron in human diet is 50 to $400 \mu \mathrm{g} /$ day. All the samples had limits below this range. 
Percent purity of salt samples vs their sources is depicted in Fig. 1. A slight variation of copper $(\mathrm{Cu})$ in living systems can lead to serious consequences such as nephrotoxic effects (Watson, 1993). Dietary requirement for copper is 150 to $600 \mu \mathrm{g} /$ day. Obtained results of copper were far below this limit. Manganese finds its utility being important in normal growth and normal reproductive functioning of reproductive organs.

Its deficiency is reason for diabetes, nervous abnormality and arthritis (Underwood, 1977). Codex Food Standard allows $2.0 \mu \mathrm{g} / \mathrm{g}$ of lead as the maximum permissible limit set by Codex Alimentarius Commission (CAC, 2006). All the obtained results in present research had values of lead far below this limit. Highest value of cadmium in our obtained results of salt samples were $0.04 \mathrm{mg} / \mathrm{kg}$. This value is also far below the values that obtained during the studies of table salt from Egypt, Turkey Greece (Soylak et al., 2008) and Iran (Khaniki et al., 2007).

\section{Conclusion}

Chemical investigation of environmental samples is important to evaluate their role on public health.Bahadur khel, Warcha and Jatta salt mines had minor contribution in rock salt production but its chemical evaluation was essential as a little was known about their chemical nature. All the minerals present in these salt samples are within the limits set by standard regarding the Codex and $\mathrm{FAO} / \mathrm{WHO}$ except the Bahadur khel salt mines, low moisture and sulphate contents implies that they can be good raw materialss.

\section{References}

Aktas,Y.K., Ibar, H. 2005. Determination of chromium, copper, manganese, nickel and zinc by flame atomic absorption spectrometry after separation of bentonite modified with trioctylamine. Journal of Indian Chemical Society, 82: 134-136.

Alam, G.S., Hussain, A., Asrarullah. 1975. The mapping of Warcha and Kalabagh salt and potash investigations, Punjab, Pakistan. Records of Geological Survey of Pakistan, 40: 14.

ASTM, 2002. Standard Test Method for Analysis of Sodium Chloride. E 534-98, American society for Testing and Materials, PA, USA.

CAC, 2006. Codex Standard for Food Grade Salt. CX STAN 150-1985, Amend, 3-2006, Codex Alimentarius Commission, pp. 1-7.
Chen, C., Qian, Y., Chen, Q., Li, C. 2011. Assessment of daily intake of toxic elements due to consumption of vegetables, fruits, meat, and seafood by inhabitants of Xiamen, China. Journal of Food Sciences, 76: 181-188.

Cheraghali, A.M., Kobarfard, F., Faeizy, N. 2010. Heavy metals contamination of table salt consumed in Iran. Iranian Journal of Pharmaceutical Research, 9: $129-132$.

Faruqi, S.H. 1983. Special features of the geology of Makarwal coal fields. In: Proceedings of the National Seminar on Development of Mineral Resources, pp. 21-24, Peshawer, Pakistan.

Gong, S.L., Berrie, L.A., Blanchet, J.P. 1997. Modeling sea-salt aerosols in the atmosphere. 1. Model development. Journal of Geophysical Research, 102: 3805-3818.

Heshmati, A., Vahidinia, A., Salehi, I. 2014. Evaluation of heavy metal contamination of unrefined and refined table salt samples. International Journal of Research Studies in Bioscience, 2: 21-24.

Khaniki, G.R.J., Dehghani, M.H., Mahvi, A.H., Nazmara, S. 2007. Determination of trace metal contaminants in edible salts in Tehran (Iran) by atomic absorption spectrophotometry. Journal of Biological Sciences, 7: 811-814.

Morris, M., Na, E.S., Johnson, A.K. 2008. Salt craving the psychobiology of pathogenic sodium intake. Psychology \& Behaviour, 94: 709-721.

Scheen, A.J., Giet, D. 2012. Role of environment in complex diseases: Air Pollution and Food Contaminants, 67: 226-233.

Sharif, Q.M., Hussain, M., Hussain, M.T., Ahmad, V.U., Raza Shah, M. 2007. Chemical evaluation of major salt deposite of Pakistan. Journal of the Chemical Society of Pakistan, 29: 570-571.

Soylak, M., Peker, D.S., Turkoglu, O. 2008. Heavy metal contents of refined and unrefined table salts from Turkey, Egypt and Greece. Environment Monitoring and Assessment, 143: 267-272.

Underwood, E.J. 1977. Trace Elements in Human and Animal Nutrition $4^{\text {th }}$ edition. Academic Press, London. UK.

Watson, D.H. 1993. Safety of Chemicals in Food; Chemical Contaminants, pp. 109-111, published by Ellis Horwood, New York, USA .

Zukowska, J., Biziuk, M. 2008. Methodological evaluation of method for dietary heavy metal intake. Journal of Food Sciences, 73: 21-29. 